\title{
Washback Effect on Second Language Acquisition Test: A Case Study of College English Entrance Exam
}

\author{
Wang $\mathrm{Yu}$ \\ School of Humanities \\ Tianjin University of Finance and Economics \\ Tianjin, PR China \\ bonnieangel@163.com
}

\author{
Bao Jie \\ School of Humanities \\ Tianjin University of Finance and Economics \\ Tianjin, PR China \\ elleneric@hotmail.com
}

\begin{abstract}
This paper focuses on a study of the washback of the college English entrance exam (CEEE). The study was motivated by a need for empirical research in keeping with the language teaching and learning reform currently underway. Questionnaire data analysis and mathematical statistics were employed in an attempt to examine how tests put impact on second language acquisition (SLA) process. The paper suggests that further reforms of language teaching and learning are supposed to be practically applied in accordance with the competence acquisition based on the requirement of CEEE.
\end{abstract}

Keywords-washback effect; SLA; CEEE; teaching and learning reform

\section{INTRODUCTION}

Washback is a term commonly used in the field of applied linguistics and is one of the issues that have attracted professional test developers' attention since the 1990's. The washback effect goes well beyond the test itself to include factors, such as curriculum, teacher and learner behaviours inside and outside the classroom and their perceptions of the test. In short, it refers to "the influence of testing on teaching and learning"[1].With the progress made in both theoretical and empirical studies of washback, it seems no longer as simple or definite as a problem of yes or no, positive or negative, etc. [2]. Scholars and educators now generally believe that testing yields both negative and positive washback. High-stakes tests of English, which largely determine the intensity of washback effect, are often chosen to be the subject of studies. By investigating the washback effect of these tests, scholars and educators try to make use of the positive effect and minimize the negative effect to promote both teaching and learning.

In China, the CEEE, which is organized and administered by the National Testing Committee, is the test of English used jointly with tests on a number of other subjects to select secondary school graduates for studies at institutions of higher learning. In 2004, an educational reform on senior high school courses was put forward by the Ministry of Education with a revised syllabus, in which the English test attached more importance on students' competence in using the language is highlighted. This paper sets CEEE under the new syllabus as a case to investigate the influence of testing second language acquisition process. We can distinguish and measure its pros and cons by understanding the CEEE washback well. And the beneficial effects can bring about more desirable changes in senior secondary school by encouraging and enlightening English teaching and learning as a whole.

\section{RESEARCH METHODOLOGY}

\section{A. Participants and Method of Sampling}

The participants in this study were students from two secondary schools and they were all CEEE -takers under the new syllabus. The age of the participants ranged from 18 to 20 with an average of 18.7. There were 55 students who responded Questionnaire1 (Q1) one month before the CEEE and Questionnaire2 (Q2) one month after the CEEE. These 55 student participants took part in a pre-college English training course one month after the CEEE.

\section{B. Sources of Data}

The study intends to investigate the washback effect of a high-stakes test (CEEE) in terms of learners. Interviews and questionnaire surveys were conducted in order to examine the influence of the test on language learning process. So, the study employed quantitative methods to collect data.

Questionnaires (Q1 \& Q2) were written in Chinese on a multiple-choice basis. The questionnaires were designed to obtain date on students' attitudes and perceptions of the CEEE and how they prepared themselves for the test. Q1 was distributed one month before they took the test and Q2 was distributed one month after they took the test. Results from these two questionnaires were compared to see the difference and changes in students' language learning before and after the test. A number of questions were quite similar in Q1 and Q2 so as to make comparisons, including language skills focused, materials used, medium of instruction of their English lessons, motivation to learn English, time allotment to study English, etc. Questionnaires derived from the framework of washback theories, namely "Washback Hypothese" [3] and "Basic Model of Washback" [4]. Besides, the author referred to questionnaires developed by Qi [5] and questionnaires developed by Cheng [6].

\section{Modles of Data Analysis}

SPSS 16.0 (Statistical Program for the Social Sciences) was employed to analyze the main source of data. Answers from the valid questionnaires were double-checked and was put into the computer. First, descriptive analysis including frequencies, means and percentages were computed to summarize Q1 and Q2. Chi-square tests were conducted with 
comparative data acquired from Q1 and Q2 to see if there were significant differences in washback effect before and after the test. Data gained from Q1 were also analyzed separately with Chi-square tests treatment to see whether the difference among levels under each examined variable was significant or not.

\section{RESULTS AND DISCUSSION}

According to Bachman and Palmer [7], the test-takers themselves can be affected by the experience of taking and, in some cases, on preparing for the test, the feedback they receive from their experience on the test, and the decisions that may be made about them on the basis of the test. Clearly, CEEE takers are affected mainly by preparing for the test, and the decisions that may be made on the basis of the test such as whether they will get entrance to famous-branded universities.

As founded in this study, different aspects of the SLA process were influenced by the practice of preparing for the CEEE test.

\section{A. Effects on Students' Learning Motivation}

Item 9 in Q1 and Item 4 in Q2 were designed to explore the effects of CEEE on students' learning motivations.

As shown in Table1, three of the four reasons listed for studying English changed significantly before and after the test $(p<0.05)$, namely to prepare for the test $(p<0.001)$, to find a good job $(p<0.001)$ and to satisfy one's own interest $(p<0.05)$. Obviously, to prepare for the CEEE was a major reason to learn English before the test while to find a good job was a much more motivating reason to learn English after the test. Generally speaking, to achieve good performances in the examination and to find good jobs in the future were the two greatest motivating factors that stimulate students to learn English. These two reasons were actually interrelated since good performance in examination could make access to better education and better education might help find better jobs.

Table1 also indicated that after the CEEE, students' learning motivation, to some extent, had switched to the satisfaction of personal interest and entertainment-related purposes. Only $3.9 \%$ of the students considered that the satisfaction of their own interest to be their learning motivation of English while the percentage climbed to $29.4 \%$ after the test $(p<0.05)$. However, the most motivating factors perceived either before or after the test were related to instrumental reasons like examinations and jobs. The intrinsic reason to satisfy personal interest-tended is less motivating comparatively.

TABLE I. STUDENTS’ MOTIVATION TO LEARN ENGLISH

\begin{tabular}{|c|c|c|c|c|}
\hline Reasons & $\begin{array}{c}\text { Pre } \\
\text { CEEE } \\
(\%)\end{array}$ & $\begin{array}{c}\text { Post } \\
\text { CEEE } \\
(\%)\end{array}$ & $\mathbf{X}^{2}$ & $\begin{array}{c}\boldsymbol{P} \\
\text { (2-sided) }\end{array}$ \\
\hline To prepare for CEEE & 76.5 & - & 63.143 & 0.000 \\
\hline To find a good job & 19.6 & 60.8 & 40.982 & 0.000 \\
\hline $\begin{array}{c}\text { To satisfy one's own } \\
\text { interest }\end{array}$ & 3.9 & 29.4 & 6.220 & 0.013 \\
\hline $\begin{array}{c}\text { To do further study or } \\
\text { study abroad }\end{array}$ & 0 & 9.8 & 0.122 & 0.727 \\
\hline
\end{tabular}

Gardner [8] noted that motivation was mainly goal-directed and strongly related to achievement. Data collected from students' interviews showed that seven of the ten students admitted studying English harder because of the CEEE and one of these seven students even admitted that he would give up the study of English if there was no CEEE. These students were highly motivated by the desire to get better scores in the CEEE. Learners with instrumental motivation for learning a second language can be successful, for the reason that providing learners with incentives may also aid learning by increasing the time studying [9].

\section{B. Effects on English Skills Focused}

As Bailey noted [10], a good test would not cease generating positive washback on the day, while the test was being administered. Thus, what kind of CEEE washback arises after its administration and the difference of washback effect on learners before and after the test are worth investigating. Item1 in Q1 and Item1 in Q2 were used to find out the major language skills that students focused on developing before and after the test. The results obtained are presented in Table2.

In general, the results indicated changes of the language skills focused by students before and after the administration of the CEEE. Before the test, reading (90.2\%) and writing (88.2\%) occupied the most amount of time and these two skills were the most frequently focused skills, followed by listening (76.5\%). Speaking (3.9\%) ranks the lowest, indicating huge gaps between speaking and other three skills. After the test, reading $(54.9 \%)$ still ranked as the most frequently practiced learning skill, followed by the skills of listening (43.1\%). The skill on which the least time was spent shifted from speaking $(27.5 \%)$ to writing $(7.8 \%)$ after the test. The results suggested that the test designers' intention to encourage reading among English learners was successful, even after the test. Take the English learning context into consideration, and it is not difficult to explain why English learners are so enthusiastic about reading practice. Since English is seldom used as the medium of everyday communication, reading plays an essential role in constituting an input to acquire the language.

Results from Chi-square tests showed that the weights assigned by students to three of four language skills experienced a significant decrease after the administration of CEEE $(p<0.01)$. The emphasis on listening and reading decreased significantly with listening from $76.5 \%$ to $43.1 \%$ $\left(\mathrm{X}^{2}=11.786, p<0.001\right)$ and with reading from $90.2 \%$ to $54.9 \%$ $\left(\mathrm{X}^{2}=15.950, p<0.001\right)$. Among all the changes, the greatest one happened to writing with the decrease from $88.2 \%$ to $7.8 \%\left(\mathrm{X}^{2}=66.023, p<0.001\right)$. In contrast, speaking tends to be emphasized more by students after the administration of the test, with percentage rose from $3.9 \%$ to $27.5 \%\left(X^{2}=10.674\right.$, $p<0.01)$. This result showed that without the pressure of preparation for the test, learners managed to take more time to use the language more communicative.

TABLE II. LANGUAGE SKILLS FOCUSED BEFORE AND AFTER THE CEEE

\begin{tabular}{|c|c|c|c|c|c|}
\hline Skills & $\begin{array}{c}\text { PreCEEE } \\
(\boldsymbol{\%})\end{array}$ & $\begin{array}{c}\text { Post CEEE } \\
(\boldsymbol{\%})\end{array}$ & $\begin{array}{c}\text { Decreased } \\
(\boldsymbol{\%})\end{array}$ & $\mathbf{X}^{\mathbf{2}}$ & $\begin{array}{c}\boldsymbol{p} \text {. } \\
(\mathbf{2} \text {-sided })\end{array}$ \\
\hline Listening & 76.5 & 43.1 & 33.4 & 11.786 & 0.001 \\
\hline Reading & 90.2 & 54.9 & 35.3 & 15.950 & 0.000 \\
\hline Writing & 88.2 & 7.8 & 80.4 & 66.023 & 0.000 \\
\hline Speaking & 3.9 & 27.5 & -23.6 & 10.674 & 0.001 \\
\hline
\end{tabular}

As shown in Table2, students were so enthusiastic about writing practice before the test but engaged themselves a lot 
less after the test $(p<0.001)$. One possible reason is the impact of the CEEE, in which the writing section occupies a large portion of the test score. In CEEE case under the new syllabus, the writing section occupies $16.7 \%$ of the test score before the revision of the university entrance examination syllabus and $20 \%$ after the revision. This encourages the test-takers to pay greater attention to practicing their writing skill before the test. However, after the test, with no pressure and no supervision from teachers, very few learners make special efforts to practice on writing. Rather than writing, when faced with English learning, students prefer to engage themselves in practicing reading skill that can be done solely by themselves without teachers' involvement.

\section{Effects on Learning Materials}

Item3, Item4, Item5 and Item6 in Q1 and Item6, Item7, Item8, and Item9 in Q2 were used to find out English learning materials before and after the test. Results obtained are presented in Table 3 .

It could be found that before the CEEE, more than half of the material chosen to study English were test-oriented. As shown in Table $3,68.6 \%$ of the listening materials, $80.4 \%$ of the reading materials and $70.6 \%$ of the writing materials were in accordance with the test format. This is the most notable washback impact on students learning materials for practicing listening, reading and writing skills $(p<0.001)$. For a high-stakes exam like the CEEE, it was not surprising to use these test-related materials to prepare for the test.

TABLE III. MATERIALS USED BEFORE AND AFTER THE CEEE

\begin{tabular}{|c|c|c|c|c|c|}
\hline Skills & Materials & $\begin{array}{l}\text { PreCEEE } \\
(\%)\end{array}$ & $\begin{array}{l}\text { PosCEEE } \\
(\%)\end{array}$ & $\mathbf{X}^{2}$ & $\begin{array}{c}p . \\
\text { (2-sided) }\end{array}$ \\
\hline \multirow{4}{*}{ Listening } & $\begin{array}{l}\text { Similar to test } \\
\text { ormat }\end{array}$ & 68.6 & 19.6 & 24.854 & 0.000 \\
\hline & Textbooks & 5.9 & 29.4 & 9.714 & 0.002 \\
\hline & $\begin{array}{l}\text { Radios, films, } \\
\text { ongs, etc. }\end{array}$ & 3.9 & 35.3 & 15.922 & 0.000 \\
\hline & None & 21.6 & 15.7 & 0.582 & 0.445 \\
\hline \multirow{4}{*}{ Reading } & $\begin{array}{l}\text { Similar to test } \\
\text { ormat }\end{array}$ & 80.4 & 15.7 & 37.920 & 0.000 \\
\hline & Textbooks & 9.8 & 66.7 & 34.913 & 0.000 \\
\hline & $\begin{array}{l}\text { English } \\
\text { hewspapers, novels, } \\
\text { tc. }\end{array}$ & 2.0 & 17.6 & 7.096 & 0.008 \\
\hline & None & 7.8 & 0 & 4.163 & 0.019 \\
\hline \multirow{4}{*}{ Writing } & $\begin{array}{l}\text { Similar to test } \\
\text { ormat }\end{array}$ & 70.6 & 2.0 & 43.049 & 0.000 \\
\hline & $\begin{array}{l}\text { Letters, diaries, } \\
\text { tc. }\end{array}$ & 5.9 & 9.8 & 0.543 & 0.412 \\
\hline & $\begin{array}{l}\text { Others forms of } \\
\text { vritings }\end{array}$ & 23.5 & 74.5 & 26.520 & 0.000 \\
\hline & None & 0 & 13.7 & 7.516 & 0.016 \\
\hline \multirow{4}{*}{ Speaking } & $\begin{array}{l}\text { Visits to English } \\
\text { orner }\end{array}$ & 2.6 & 25.5 & 11.922 & 0.001 \\
\hline & $\begin{array}{|ll|}\text { Talk } & \text { with } \\
\text { oreigners } & \\
\end{array}$ & 2.6 & 0 & 1.010 & 0.315 \\
\hline & Reading aloud & 56.4 & 60.8 & 0.994 & 0.319 \\
\hline & None & 38.5 & 13.7 & 12.089 & 0.001 \\
\hline
\end{tabular}

Table3 also showed that after the CEEE, the use of authentic materials in developing listening and reading skills increased sharply. As many as $35.3 \%$ of the students listened to English programs and songs or watch films to practice their listening skills, compared with $3.9 \%$ before the test $(p<0.001)$. As many as $17.6 \%$ of the students read English papers and novels compared with only $2.0 \%$ of them before the test $(p<0.01)$. This can be regarded as a negative washback of the CEEE since the materials students used before the test tended to be less authentic and less communicative.

Moreover, it can be seen from the table that either before the test or after the test, students practiced their oral English mainly by reading aloud to themselves, $56.4 \%$ before the test and $60.8 \%$ after the test, indicating no significance change before and after the test $(p>0.05)$. They rarely had chances to communicate with native speakers either before the test $(2.6 \%)$ or after the test $(0 \%)$. However, Table3 clearly shows that students tended to have more opportunities in practicing their oral English after the CEEE. The chances to visit English corners rose from $2.6 \%$ to $25.5 \%(p<0.01)$ while the chances of total abandonment of speaking decreased from $38.5 \%$ to $13.7 \%(p<0.01)$. This result could be explained by the negative washback of CEEE on speaking, which hindered the communicate learning of English.

\section{Effects on Students' Preferences}

Item 11, Item 12 and Item 13 in Q1 were designed to explore students' learning preferences in the CEEE preparation classes. The results obtained are presented in Table4, Table5 and Table6. Results of students' interviews supplemented the data from Q1 and Q2.

Table4 showed that more than half of the students $(62.7 \%)$ preferred to do test papers with teachers' explanation while none of them preferred to do test papers without teachers' explanation. This indicated that in CEEE preparation, classes tend to be teacher-oriented. As many as $37.3 \%$ the students preferred to ask for teachers' explanation when necessary. Chi-square test showed that there was no significant difference between students' preference on doing test paper with teachers' explanation and asking for teachers' explanation when necessary $(p>0.05)$. This implied the students' preference on combination of self-study with teachers' guidance in the learning of English and may serve as a hint that a certain number of students have realized the importance of self-study in the English learning process.

TABLE IV. STUDENTS' PREFERENCE OF TEST PAPER

\begin{tabular}{|c|c|c|c|}
\hline Ways & $\begin{array}{c}\text { Percentage } \\
(\mathbf{\%})\end{array}$ & $\mathbf{X}^{\mathbf{2}}$ & $\boldsymbol{p}$. \\
\hline With teachers' explanation & 62.7 & \multirow{2}{*}{3.314} & 0.069 \\
\hline $\begin{array}{c}\text { Ask for teachers' explanation when } \\
\text { necessary }\end{array}$ & 37.3 & & \\
\hline Without teachers' explanation & 0 & \multicolumn{2}{|c|}{} \\
\hline
\end{tabular}

Table5 showed that more than half of the students $(58.8 \%)$ preferred CEEE-related teaching content, differing significantly from non-CEEE teaching content $(p<0.001)$. Take the oncoming test into consideration; it is not surprising for the students to show their preference on the test-related teaching content since most of them have strong determination to succeed in the test and this indicates the strong washback of CEEE. 
TABLE V. STUDENTS' PREFERRED TEACHING CONTENT

\begin{tabular}{|c|c|c|c|}
\hline Contents & $\begin{array}{c}\text { Percentage } \\
(\mathbf{\%})\end{array}$ & $\mathbf{X}^{\mathbf{2}}$ & $\boldsymbol{p}$. \\
\cline { 1 - 2 } CEEE-related, mock test papers & 58.8 & \multirow{2}{*}{18.471} & \multirow{2}{*}{0.000} \\
\cline { 1 - 2 } English movies, theatres, newspapers & 31.4 & & \\
\hline English textbooks & 9.8 & &
\end{tabular}

Another noticeable finding shown in Table5 was that even in the last month before the CEEE, as many as $31.4 \%$ of the students still preferred to learn more authentic materials.

Table6 showed that a majority of students $(76.5 \%)$ would participate actively if teachers organize activities like watching movies related to CEEE during the test preparation period. The number of students who preferred to participate in this kind of activities far out-weighed the number of those who didn't prefer $(5.9 \%)$ or didn't care $(17.6 \%)$ ( $p<0.001)$.

TABLE VI. STUDENTS' PREFERENCE ON LEARNING BEHAVIORS

\begin{tabular}{|c|c|c|c|}
\hline Behaviors & $\begin{array}{c}\text { Percentage } \\
(\boldsymbol{\%})\end{array}$ & $\mathbf{X}^{\mathbf{2}}$ & $\boldsymbol{p}$. \\
\hline Participate actively & 76.5 & \multirow{2}{*}{43.765} & \multirow{2}{*}{0.000} \\
\hline Do not participate & 5.9 & & \\
\hline Do not care & 17.9 & & \\
\hline
\end{tabular}

\section{E. Effects on Students' Learning Strategies}

CEEE is a high-stakes test that exerts a strong impact on test-takers. Item 22 in Q1 was intended to explore the learning strategies used by students during the test preparation period. Results from the questionnaire are presented in Table 7 based on Oxford's (1990) classification of learning strategies.

Functional practice strategies include actively seeking or creating opportunities to use or practice English functionally. These strategies enable learners to increase their exposure to the target language outside the formal classroom. Table 7 showed some of the functional practice strategies used by students in test preparation classes: reading as much as possible in English (27.5\%), asking questions for clarification of English (37.3\%), noticing English errors to help learn better (29.4\%). This could be understood that the strategies of asking for clarification of English and noticing English errors to promote learning can help learners grasp standard language form which is examined in standardized language tests like the CEEE. The strategy, reading as much as possible in English, was applied due to the emphasis on reading ability in the CEEE.

Cognitive-memory strategies involve direct analysis, transformation, association, or synthesis of the target language and that will consequently facilitate the memory process. The study showed that during the test preparation period, some of the cognitive-memory strategies were very frequently used. The most frequently used strategies included: taking notes (64.7\%), doing grammar exercises $(51.0 \%)$, finding the meaning of words by dividing them into parts (37.3\%), using translation to help learn English (37.3\%), etc. The use of these strategies agreed with Ellis's (1994) when he made the point that paying attention to the formal properties of the target language contributed to successful language learning. And the attention paid on the formal properties of the target language may be seen as one of the impacts of the CEEE on language learning.
TABLE VII. STUDENTS' LEARNING STRATEGIES INVOLVED IN TEST PREPARATION

\begin{tabular}{|c|c|c|c|}
\hline Strategies & $\begin{array}{l}\text { Number } \\
\text { of item }\end{array}$ & \begin{tabular}{|l|}
$\begin{array}{l}\text { Percentage } \\
(\%)\end{array}$ \\
\end{tabular} & \begin{tabular}{|c|} 
Average \\
Percentage $(\%)$
\end{tabular} \\
\hline \multirow{3}{*}{$\begin{array}{l}\text { Functional practice } \\
\text { strategies }\end{array}$} & Q1-22-2 & 27.5 & \multirow{3}{*}{31.4} \\
\hline & Q1-22-4 & 37.3 & \\
\hline & Q1-22-6 & 29.4 & \\
\hline \multirow{8}{*}{$\begin{array}{l}\text { Cognitive- } \\
\text { memory strategies }\end{array}$} & Q1-22-8 & $23 . .5$ & \multirow{8}{*}{34.325} \\
\hline & Q1-22-9 & 35.3 & \\
\hline & Q1-22-10 & 21.6 & \\
\hline & Q1-22-11 & 64.7 & \\
\hline & Q1-22-12 & 37.3 & \\
\hline & Q1-22-13 & 51.0 & \\
\hline & Q1-22-14 & 25.5 & \\
\hline & Q1-22-15 & 15.7 & \\
\hline \multirow{5}{*}{$\begin{array}{l}\text { Metacognitive } \\
\text { strategies }\end{array}$} & Q1-22-19 & 41.2 & \multirow{5}{*}{37.66} \\
\hline & Q1-22-20 & 37.3 & \\
\hline & Q1-22-21 & 37.3 & \\
\hline & Q1-22-22 & 43.1 & \\
\hline & Q1-22-23 & 29.4 & \\
\hline \multirow{2}{*}{$\begin{array}{l}\text { Compensation } \\
\text { strategies }\end{array}$} & Q1-22-24 & 37.3 & \multirow{2}{*}{46.1} \\
\hline & Q1-22-25 & 54.9 & \\
\hline $\begin{array}{l}\text { Formal oral practice } \\
\text { strategies }\end{array}$ & Q1-22-16 & 52.9 & 52.9 \\
\hline \multirow{3}{*}{ Social strategies } & Q1-22-17 & 7.8 & \multirow{3}{*}{9.8} \\
\hline & Q1-22-18 & 2.0 & \\
\hline & Q1-22-26 & 19.6 & \\
\hline
\end{tabular}

Metacognitive strategies give learners control over their own learning and these strategies exercise "executive control" over one's language learning through planning, monitoring, and evaluating. As many as $41.2 \%$ students pay close attention to their progresses in learning English. Nearly one third of them $(29.4 \%)$ of them made plans for English learning while $37.3 \%$ of them set goals for improving English. Less than one half of the students $(43.1 \%)$ tried their best to find better ways to learn English while 29.4\% of them reviewed English frequently. This indicated that students made great efforts to make their learning process more systematic and effective when faced with high-stakes test.

Compensation strategies enable students to make up for missing knowledge in the process of comprehending or producing the target language. As many as $37.3 \%$ of students made guesses to understand words that they don't know while more than half of the students $(54.9 \%)$ read English without looking up every new word. The employment of these strategies might be viewed as a result of the emphasis laid on reading comprehension in the CEEE. The reading part in the CEEE covers a large vocabulary and it is natural for the students to come across new words that they do not know, especially under the new syllabus. However reading plays a more important role in the test of both multiple-choice questions and open-ended questions. The strategies of guessing the meaning of words can help the students better comprehend the reading materials within limited time.

Oxford [11] noted that formal oral-practice strategies focus on formal practice for speaking English, such as practicing the sounds of English, trying to imitate native English speakers, repeating new English words, and paying attention when someone is speaking English. However, data from this study indicated that during the test preparation period, the most commonly used strategy was repeating or writing new English words several times $(52.9 \%)$. A possible reason for this may 
be that the CEEE has a required vocabulary in recent years. For example, the CEEE paper required a vocabulary of 2,003 words in the testing syllabus in 1999 [12]. In 2007, under the revised version of the university entrance examination syllabus, the required vocabulary climbed to 3,300 words [13]. This motivated the students to use the strategy of repeating or writing new English words several times to remember more words.

Social strategies often involve the participation of other people, which are mainly concerned with oral communication, such as talking with foreigners or teachers and asking them to make corrections. Since the CEEE does not have a speaking section, it is not surprising to find that students employed minimal social strategies $(9.8 \%)$ during the test preparation period.

Therefore, it could be concluded that language learning strategies that were frequently used by students during the test preparation period seemed to mainly relate to reading and vocabulary learning. In addition, the various uses of metacognitive strategies indicated that students were highly motivated by the CEEE. Students' preferred learning strategies reflected their determinations and wishes to get high scores in the CEEE. So, it is evident that the CEEE plays a crucial role in enabling the students to employ various strategies to learn English.

\section{CONCLUSION}

\section{A. Summary of the Study}

Tests, especially high-stakes tests, are perceived to have considerable washback effect on teaching and learning. This empirical study takes the CEEE to explore the washback effect of English tests in terms of SLA process.

It is found that CEEE has a strong washback effect on SLA process. Students' learning motivation, learning skills and materials differed significantly before and after the CEEE. A variety of strategies were used to make the learning process more efficient when faced with CEEE. Moreover, even during the test preparation period, students expressed their wishes to conduct the learning activities in a more interactive and interesting way. In a word, the CEEE has strongly influenced the learning of English in senior secondary schools both positively and negatively.

\section{B. Pedagogical Implications}

The investigation into CEEE demonstrates that in China, high-stakes tests do affect both what and how students learn. To improve the learning of English, researchers have to focus on how to produce the beneficial washback of English tests. This study is meaningful, which provides us with some pedagogical implications on English learning.

Furthermore, high-stakes English tests usually have a positive effect on the contents and skills that are included in the tests. For example, the preparation of the CEEE has a positive effect on language learners' listening, reading and writing skills, which are included in the test while skills such as speaking are often neglected. Taking this into consideration, educators and syllabus-makers can improve language communicative competence of learners by reforming and optimizing the formats and contents of language tests.

In addition, as what has been found in this study, a lot of the harmful impact of the CEEE such as hindering the interests of learners and narrowing the learning materials are caused by the nature of CEEE. It is such a high-stakes test that it even determines the future of the learners. To reduce the negative effect, the stakes of some important English tests should be lowered to some extent. CEEE can be changed from a summative assessment to a part of formative assessment. Students' enrollment to universities will no longer depend on one single test, but a series of regular tests. In this way, students could concentrate more on improving language acquisition competence.

\section{ACKNOWLEDGMENT}

Supported by Tianjin Philosophy \& Social Science Foundation, China (TJWY12-016)

\section{REFERENCES}

[1] L. Cheng and A. Curtis, "Washback or backwash: A review of the impact of testing and learning," in Washback in language testing: Research contexts and methods L. Cheng, Y. Watanabe and A. Curtis, Eds. Mahwah, NJ: Lawrence Erlbaum \& Associates, 2004, pp. 3-17.

[2] J. C. Alderson and D. Wall, "Does washback exist?" Applied Linguistics, vol. 14(2), pp. 115-129, 1993.

[3] J. C. Alderson and L. Hamps-Lyons, "TOEFL preparation courses: A study of washback.” Language Testing, vol. 13(3), pp. 280-297, 1996.

[4] K. M.Bailey, "Working for washback: A review of the washback concept in language testing." Language Testing, vol. 13(3), pp. 257-279, 1996

[5] L.X. Qi, The intended washback effect of the National Matriculation English test in China: intentions and reality. Beijing: Foreign Language Teaching and Research Press, 2004.

[6] L. Cheng, "How does washback influence teaching? Implications for Hong Kong." Language and Education, vol. 11(1), pp. 38-54, 1997.

[7] L. F. Bachman and A. S. Palmer, Language testing in practice. Oxford: Oxford University Press, 1996.

[8] R. C. Gardner, Social psychology and second language learning: The role of attitudes and motivation. London: Edward Arnold, 1985.

[9] R. Ellis, The study of second language acquisition. Oxford: Oxford University Press, 1994.

[10] K. Bailey, Washback in language testing. New Jersey: Educational Testing Service, 1999.

[11] R. L. Oxford, Language learning strategies: What every teacher should know. New York: Newbury House Publishers, 1990.

[12] NMET Syllabus. Beijing: Higher Education Press,1999.

[13] NMET Syllabus. Beijing: Higher Education Press,2007. 